\begin{tabular}{|c|c|c|c|}
\hline Article Info & RESEARCH ARTICLE & ARAŞTIRMA MAKALESİ & \\
\hline Title of Article & \multicolumn{2}{|c|}{$\begin{array}{l}\text { Public and Ecological Significance of Fringe } \\
\text { Belts: The Case of Military Areas in Izmir }\end{array}$} & \\
\hline $\begin{array}{l}\text { Corresponding } \\
\text { Author }\end{array}$ & \multicolumn{2}{|c|}{$\begin{array}{l}\text { Dalya HAZAR } \\
\text { Pamukkale Üniversitesi, Mimarlık ve Tasarım Fakültesi, Şehir ve Bölge } \\
\text { Planlama Bölümü, dalyahazar@gmail.com }\end{array}$} & \\
\hline $\begin{array}{l}\text { Received Date } \\
\text { Accepted Date }\end{array}$ & \multicolumn{2}{|l|}{$\begin{array}{l}03.02 .2020 \\
17.04 .2020 \\
\end{array}$} & \\
\hline Author / Authors & $\begin{array}{l}\text { Dr. Öğr. Üyesi Dalya HAZAR } \\
\text { Öğr. Gör. Dr. Sevim Pelin ÖZKAN }\end{array}$ & $\begin{array}{l}\text { ORCID: 0000-0003-0075-0234 } \\
\text { ORCID: 0000-0003-2049-6771 }\end{array}$ & \\
\hline How to Cite & \multicolumn{2}{|c|}{$\begin{array}{l}\text { HAZAR, D. and ÖZKAN, S. P. (2020). Çeper Kuşakların Kamusal ve Ekolojik Değeri: } \\
\text { İzmir Askeri Alanlar Örneği, Kent Akademisi, Volume 13, Issue 1, 10-21. }\end{array}$} & $\begin{array}{l}\text { Kent Akademisi } \\
\text { Urban Acaderny }\end{array}$ \\
\hline
\end{tabular}

\title{
Çeper Kuşakların Kamusal ve Ekolojik Değeri: İzmir Askeri Alanlar Örneği
}

\section{ABSTRACT:}

The fringe belt concept that has been handled morphologically by urban geographers since the 1960 s has recently gained increasing attention in the urban planning and design spheres. Fringe belts are the former urban peripheries that are embedded within the city in the historical process. Fringe belts continue to contain the peripheral land uses that are important for urban ecology and sustainable urban development. The fringe belt concept is crucial in order to grasp the morphological growth of the city by understanding the location, function and the significance of the fringe belts to see the effects of different planning approaches on these areas. Fringe belts often feature as urban heritages and ecological corridors and they create a buffer zone that protects natural areas against the negative effects of the city. In addition, they reduce the urban heat island effect by their frequent use of open and green areas. Yet, due to the rapid urbanization and the search for the empty lands, fringe belts are embedded within the city center and its surroundings are exposed to alienation. Fringe belt alienation should be seen as one of the basic problems of the urban development. This study focuses on the military areas that form a part of the fringe belts in İzmir and are predicted to be extramuralized in the near future. As a response to the extramuralization risk, this study evaluates the effects and potential of military areas, which form a part of fringe belts in İzmir, as open green areas on urban ecology and on public interest and this study suggests urban fringe belt planning against the possible alienation risks.

KEYWORDS: Urban fringe belt, urban morphology, urban ecology, military area, GIS, İzmir.

\footnotetext{
${ }^{1}$ Pamukkale University, Faculty of Architecture and Design, Department of Urban and Regional Planning, dalyahazar@gmail.com

${ }^{2}$ Muğla Sıtkı Koçman University, Yatağan Vocational School, Department of Land Registry and Cadastre, seplnz@gmail.com
} 
ÖZ:

1960'lı yıllar itibariyle kent coğrafyacıları tarafından morfolojik açıdan ele alınan çeper kuşak kavramı, son yıllarda kentsel planlama ve tasarım alanlarında artan bir ilgi görmektedir. Çeper kuşaklar, tarihsel süreçte kent içine gömülü kalmış eski kent çeperlerini oluşturan sınırları temsil ederler. Çeper kuşaklar, kent ekolojisi ve sürdürülebilir kentsel gelişim için önemli olan periferik arazi kullanımlarını barındırmaya devam etmektedir . Çeper kuşak kavramı; çeper kuşakların kentteki yerini , fonksiyonunu ve değerini kavrayarak ve bu alanla r üzerindeki farklı planlama yaklaşımlarının etkilerini görerek kentin morfolojik gelişimini anlamak açısından önemlidir. Çeper kuşaklar sıklıkla kent mirası ve ekolojik koridor özellikleriyle tampon bölge yaratarak kentin doğal alanlar üzerindeki negatif etkilerini azaltabilirler. Ayrıca, sıklıkla açık ve yeşil alan kullanımlarıyla kentsel ısı adası etkisini azaltıcı etki gösterirlerAncak hızlı kentleşme ve boş arazilere duyulan ihtiyaç sonucunda , kent merkezi ve çevresindeki çeper kuşaklar yabancılaşmaya maruz kalmaktadır. Çeper kuşak yabancılaşması, kent gelişiminin temel sorunlarından biri olarak ele alınmalıdır. Bu çalışma, İzmir'deki çeper kuşakların bir parçasını oluşturan ve yakın gelecekte şehir dışına taşınacağı tahmin edilen askeri alanlara odaklanmaktadır. Şehir dışına taşınma riskine yanıt olarak, bu çalışma İzmir'de çeper kuşakların bir parçasını oluşturan askeri alanların açık yeşil alanlar olarak kentsel ekoloji ve kamu yararına etkilerini ve potansiyelini değerlendirmekte ve olası yabancılaşma risklerine karşı kentsel çeper kuşak planlaması önermektedir.

ANAHTAR KELIMELER: Kentsel çeper kuşak, kentsel morfoloji, kentsel ekoloji, askeri alan, CBS, İzmir.

\section{"Çeper Kuşakların Kamusal ve Ekolojik Değeri: İzmir Askeri Alanlar Örneği”"}

\section{Gíriș:}

Son yıllarda askeri alanların kent dışına taşınması çeşitli kurum temsilcileri tarafindan sıklıkla dile getirilmektedir . Askeri alanların kent dışına taşınması durumunda çoğu geniş parseller ve açık yeşil alan kullanımları barındıran bu alanların nasıl değerlendirileceği planlamanın kamu yararı ilkesi açısından kritik bir konudur. Özellikle kent merkezi ve çevresinde kalan alanların ciddi bir yapılaşma baskısı altında kalabileceği ve spekülatif kentsel rant uğruna kaybedilebileceği ilgili meslek odaları ve akademisyenler tarafından çok defa belirtilmiştir.

Askeri alanlar, kentsel morfoloji yazınında önemli bir kavram olan çeper kuşaklar içerisine dahil edilmektedir (Conzen, 2009; Hazar \& Kubat, 2015). Daha ucuz ve geniş alan ihtiyacı, gözden uzak olma istemi, coğrafi özellikler vb. sebeplerle kent çeperinde yer arayan çeper kuşak alanları, tarihsel süreçte kentin büyümesiyle birlikte kent içine gömülü kalır. Çeper kuşaklar eski periferik kullanımlarını sürdürebilir, bir başka çeper kuşak kullanımına dönüşebilir ya da çeper kuşak karakteristiklerini kaybederek yabancilaşabilirler. Yeşil alanlar (ör. kent park1, bostan), endüstriyel kullanımlar (ör. depo alanı), kurumsal kullanımlar (ör. askeri alan, üniversite kampüsü) ve spor alanları (ör. stadyum) çeper kuşak kullanımları içerisinde sayılmaktadır . Çoğu zaman kentsel miras alanı ve ekolojik koridor özellikleri gösteren çeper kuşaklar, kent merkezi ve çevresinde görece daha fazla dönüşüm baskısı altında kalmaktadır. Bu bağlamda, merkez ilçelerde gömülü kalmış ve potansiyel kent parkı ve kamusal alan özelliklerine sahip askeri alanların kent dışına taşınması söz konusu olursa, bu durumun çeper kuşak yabancılaşmasına sebep olup olmayacağı önemli bir araştırma konusudur.

Kent içinde kalan askeri alanların kamusal alana ve kent parkına dönüşümüne dair dünyada çeşitli örnekler bulunmaktadır (ör. Barselona, Citadel Parkı). Türkiye'de ise özellikle 2016 yılı ardından ulusal güvenlik kaygılarıyla dile getirilmeye başlanan askeri alanların şehir dışına taşınması konusunda, bu alanları potansiyel kent parkları, kentsel dönüşüm rezerv alanları ya da sermayenin yer seçebileceği yeni mekanlar olarak değerlendiren farklı görüşler ortaya çıkmış ve bu alanların dönüşüm sürecinde nasıl bir yol izlenmesi gerektiğine dair Türkiye genelinde durum incelemesi yapmak üzere Çevre ve Şehircilik Bakanlığı (ÇŞB), Maliye Bakanlığı ve Milli Savunma Bakanlığından oluşan komisyonlar kurulmuştur. Çevre ve Şehircilik Bakanı, şehir içinde kalan askeri alanların "imara açılmayacağını" ve özellikle yeşil alanların kentlilerin kullanımına sunulacağını ifade eden basın açıklamaları da yapmıştır (Url-1; Url-2). Ancak söz konusu komisyon raporlarına ulaşılamamıştır ve kent içindeki askeri alanların durumu halen belirsizliğini ve gelecekte imara açılma riskini sürdürmektedir.

Yapılan çalışma, İzmir'deki askeri alanları kentsel morfoloji literatürünün çeper kuşak kavramı içerisinde değerlendirmekte; Coğrafi Bilgi Sistemleri (CBS) araçları kullanarak mekansallaştırmakta ve bu alanların kentsel 
ekolojiye ve kamu yararına etkisine odaklanarak olası yabancılaşma risklerine karşı yeşil altyapı stratejileriyle entegre edilebilecek bir çeper kuşak planlaması önerilmektedir.

\section{1. Çeper Kuşak Alanı Kavramı}

Çeper kuşak alanlarına dair ilk geniş kapsamlı tanımı, İngiltere Alnwick’te yaptığı çalışmaların ardından M .R.G. Conzen (1969) yapmıştır: "Çeper kuşak alanı, geçici ya da çok yavaş büyüyen bir kent çeperinden kaynaklanan ve başlangıçta çeperde yer arayan arazi kullanım birimlerinin karakteistik karışımından oluşan kuşak benzeri bölgedir." (Conzen, 1969, 125). Kısaca özetlemek gerekirse çeper kuşak, planlardan bağımsız olarak ya da plansız alanlarda kendiliğinden yer seçen kullanımların kemikleşmesi (fosilleşmesi) ile oluşan ve kent büyümesiyle kent içine gömülü kalan eski kent çeperidir.

Zaman içerisinde, gelişim, dönüşüm ve koruma planlarına maruz kalabilen çeper kuşaklar , kentin morfolojik gelişimini anlamak için önemlidir. Çeper kuşaklar ayrıca kent ekolojisi ve sürdürüle bilirlik için ve kültürel ve doğal özellikleri sebebiyle değerlidir. Bir kısmı kullanılmayan, atıl durumda olan (ör. endüstiyel miras alanları) çeper kuşak alanları günümüzde kamusal değeri açısından yeniden düzenlenmeye ihtiyaç duymaktadırBu alanlar, karar vericilere, daha düşük yoğunluklu karma alanlar planlama olanağı vermektedir . Ancak bu süreç , özgün çeper kuşak karakteristiğini kaybetme riskini de yaratmaktadır (Barke, 1990; Conzen, 2009; Gu, 2010).

Çeper kuşaklar, kendiliğinden ortaya çıkmaktadır ve fiziksel, sosyo-ekonomik ve kültürel etkileşimlere göre sürekli olmaktadır. Bu sebepten, özellikle kemikleşmiş (fosilleşmiş) çeper kuşaklar, kentsel kolektif bellek açısından (Rossi, 1982; Halbwachs, 1950) çok önemli unsurlardır. Çeper kuşaklar, kuruluş amacıyla kullanılmaya devam edilirlerse , sürekli olurlar ve sağlamlaşırlar . Çeper kuşaklar, kent içerisindeki konumları ve tarihsel geçmişlerine göre 3'e ayrılmaktadır: iç çeper kuşak, orta çeper kuşak ve dış çeper kuşak. Oluşum zamanı açısından bakıldığında ilk olarak iç çeper kuşak oluşur ve tarihsel süreçte kent merkezi içi ve çevresinde gömülü kalır . Çeper kuşak, kent merkezinin içinde ya da çevresindeyse, özgün karakterin üzerindeki değişim baskısı görece fazla olur Ancak, çeper kuşak tarihsel süreçte değişse de , genellikle çevresindeki dokudan farklı olmayı sürdürür (Whitehand, 1967). Çeper kuşak değişiminde, alan bir başka çeper kuşak kullanımına geçer (ör. İzmir Tarihi Havagazı Fabrikası Kültür Merkezi). Çeper kuşak yabancılaşmasında ise, ticaret ve konut alanı baskısı sonucunda çeper kuşak özgün karakteri kaybeder (ör. Eczacıbaşı ilaç depolarının Kanyon AVM'ye dönüşmesi ). Yetersiz kentsel stratejiler ve planlama politikaları , çeper kuşak sürekliliğini engelleyen etmenlerin başında gelmektedir (Kubat \& Hazar, 2018).

Kent morfolojisi ve planlama arasındaki etkileşim son yıllarda artış göstermekle birlikte, çeper kuşak kavramı henüz planlama literatürü ve pratiğinde yeterince tartışılmamıştır (Barke, 2019; Whitehand \& Gu, 2017; Gu, 2010; Whitehand \& Morton, 2003, 2004). Çeper kuşaklar, bütüncül bir kent planı oluşturmak için önemli kentsel elemanlardır. Bu sebepten, kent tarihinin ve kentsel ekolojinin ayrılmaz parçaları ve planlama pratiklerinin tamamlayıcı bileşenleri olarak ele alınmaları gerekmektedir (Whitehand \& Morton, 2003; Ünlü, 2013). Bunun yanı sıra, kent içi yeşil alan tasarımı ve çeper kuşaklar arasındaki ilişkinin güçlendirilmesini öneren çalışmalar da bulunmaktadır (Ducom, 2003; Kukina, 2006).

Türkiye'de çeper kuşak çalışmaları henüz yeni ve sayıca azdır; (1) İstanbul ve Barselona kentleri karşılaştırmalı çeper kuşak analizi (Hazar, 2012; Hazar \& Kubat, 2015); (2) Mersin iç çeper kuşak analizi (Ünlü, 2013); (3) İstanbul iç çeper kuşak analizi (Hazar \& Kubat, 2016; Kubat \& Hazar, 2018); (4) Çok merkezli metropoliten şehirlerde çeper kuşak analizi (Ünlü \& Baş, 2016; Ünlü \& Baş, 2019); (5) Çeper kuşakların mekansal büyüme üzerindeki etkisi (Kaya \& Akdemir, 2019); (6) İstanbul'un çok merkezli çeper kuşak analizi (Kubat, 2019); ve (7) Çeper kuşakların yeşil altyapı stratejileri açısından önemi (Hazar \& Özkan, 2019). Çeper kuşak kavramı, planlama, kentsel tasarım, sürdürülebilir yönetim stratejileri ve kültürel boyutla ilişkilenerek zenginleşmektedir; ancak potansiyel bir planlama ve tasarım aracı olarak literatürde daha fazla ilgiyi hak etmektedir.

\section{2. Çalışma Alanı: İzmir Askeri Alanları}

Kent merkezindeki askeri alanların kent dışına taşınması özellikle 2016 yılı sonrasında ulusal güvenlik kaygılarının artmasıyla birlikte yeniden gündeme gelmiştir. Afet toplanma alanları dahil kent içinde (özellikle merkez ilçelerde) kalan boş parsellerin imar baskısı altında kalma riski, askeri alanlara bir koruma refleksiyle yaklaşılması gerekliliğini ortaya çıkarmıştır. İzmir kenti içerisinde birçok askeri alan bulunmaktadır. Bornova ilçesinde bulunan Doğanlar Askeri Alanı, gündeme gelen ilk alan olarak önemlidir. Çünkü bu alanda imar planları aracılığıyla yapılacak değişiklikler, İzmir'deki tüm askeri alanlara emsal oluşturabilecek niteliktedir. 
Büyük kısmı ağaçlık alan olan ve orman statüsü alması gereken arazi, 2016 yılında ÇŞB onayıyla yapılaşmaya açılmak istenmiştir. Alanda 'rant yaratıldığı' gerekçesiyle meslek odaları tarafindan açılan davalar ile imar planları iptal edilmiştir. Alan 2018 yılında Milli Savunma Bakanlığı tarafindan TOKİye devredilmiş ve ardından satışa çıkarılarak yeniden özel mülkiyete konu edilmiştir. Yapılan yeni planlar ile alanda kamu yararı ilkesi göz ardı edilmiş ve kamusal alanlar, başta toplu işyerleri, ticaret, akaryakıt + LPG istasyonları olmak üzere özel mülkiyete devredilmeye çalışılmıştır. Bunun sonucunda, meslek odaları yeniden hukuki mücadele başlatmışlardır. Davaların bir kısmı odaların lehine sonuçlanmış ve bir kısmı henüz sonuçlanmamışken yeni planlar askıya çıkarılmıştır. Bu davalarla birlikte, TOKİ'nin son yıllarda, kuruluş amacıyla ilgisi olmayan bir biçimde, arsa temini için bir araç haline getirildiği görülmektedir (TMMOB İzmir İKK, 2018). Mevcut durumda askıdaki yeni planlara meslek odalar1 tarafindan yeniden dava açılması gündemdedir.

Orman statüsünde korunması gereken ve İzmir'in kent içerisinde kalmış değerli çeper kuşaklarından biri olan Doğanlar askeri alanın yapılaşmaya açılması yerine; kent içinde eksikliği fazlasıyla hissedilen donatı ihtiyaçlarını karşılayabilecek bir kent parkına dönüştürülmesi önerilmektedir (TMMOB İzmir İKK, 2018; Url-3). Mevcutta yoğun kamusal kullanımlar barındıran çeper kuşak alanlarının ve özelde askeri alanların, kuruluş amacıyla kullanılmaya devam edilmesi ya da kullanım değişikliğine uğraması durumunda, kamusal kullanımını sürdürmesi kentsel ekolojik sürdürülebilirlik ve kamu yararı için hayati önem taşımaktadır (Şekil 1).

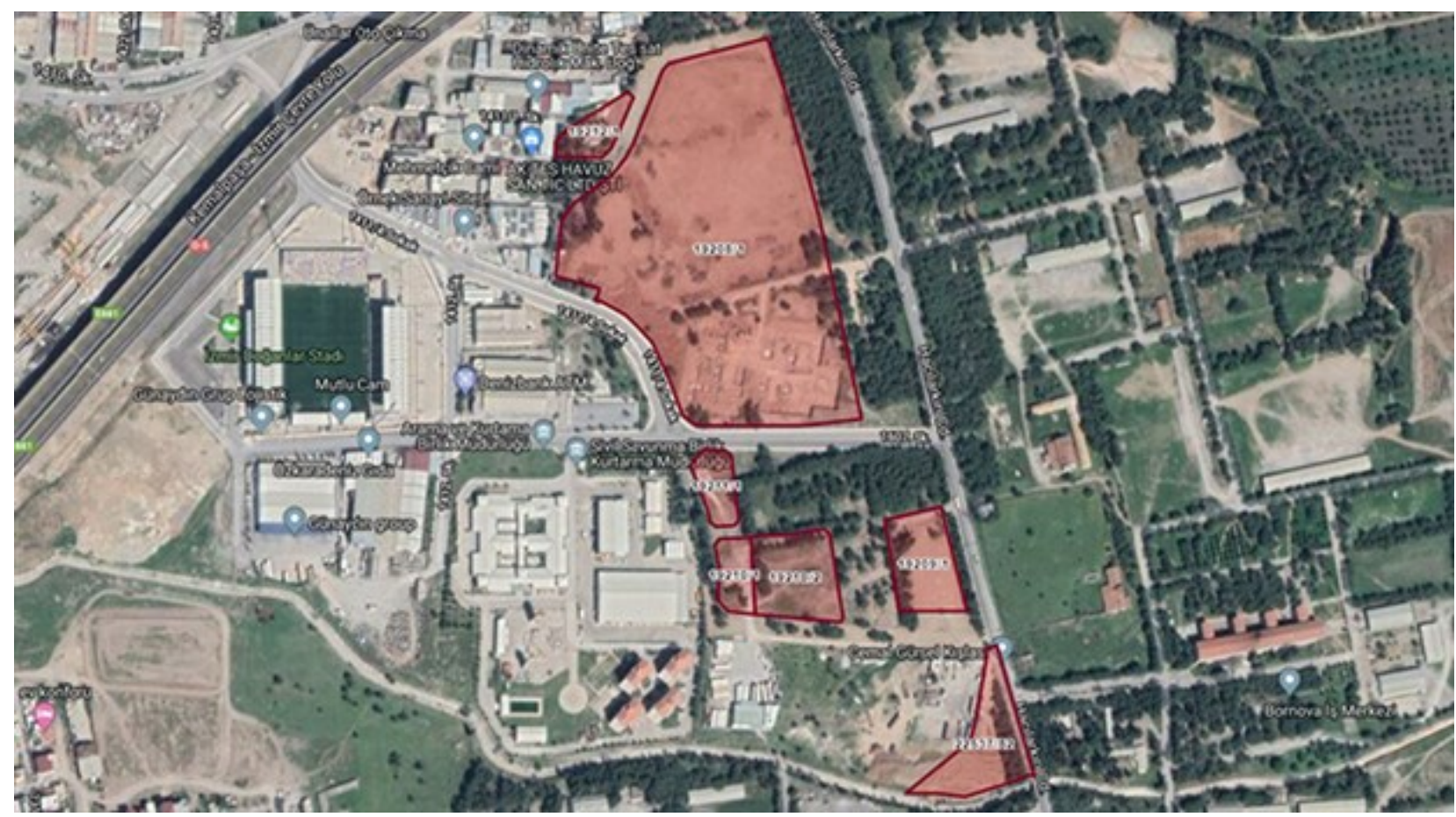

Şekil 1. Bornova Doğanlar Askeri Alanı (Url-3).

Bornova Doğanlar Askeri Alanı, söz konusu dava süreçleriyle TMMOB İzmir İl Koordinasyon Kurulu tarafindan 2019 yılında çevrimiçi olarak yayınlanan 'İzmir Kent Suçları Haritası' içerisindeki 72 kent suçundan biri olarak kaydedilmiştir (TMMOB İzmir İKK, 2019). Alan İzmir'de İstinyepark AVM davasında olduğu gibi, henüz dava süreçleri sonuçlanmadan projenin uygulanarak tamamlanması ve yapılaşmanın geri dönüşsüz biçimde dava sürecinden önce tamamlanması riskini taşımaktadır. İzmir özelinde kent suçlarını, gelişme ve kalkınma söylemleri ve sermayenin yeni mekân arayışları sürecinde kentin potansiyel bir çekim noktasına dönüşmesi açısından ele almak gereklidir. Özkan ve arkadaşları (2019), İzmir inşaat sektörü özelinde sermaye hareketliliğini inceledikleri çalışmalarında, ulaşım yatırımları, konut, rezidans, AVM vb. inşaat yatırımları ile birlikte arsa, konut, dükkân kiralarının artan oranda yükseldiğini görgül biçimde ortaya koymuşlar ve Çeşme, Urla, Bayraklı, Konak, Bornova ve Karşıyaka ilçeleri başta olmak üzere, rezidans, konut, AVM projelerinin üretimi önündeki engellerin ayrıcalıklı imar hakları ve parsel bazlı imar değişiklikleriyle kaldırılması sonucunda İzmir kentinin sermaye açısından daha kârı bir alan haline dönüştüğü değerlendirmesinde bulunmuşlardır. 
Askeri alanların kent dışına taşınması durumunda yabancılaşma riski altında bulunan bir diğer çeper kuşak örneği, Üçkuyular askeri alanıdır. Alan, Sekil 2'de görüldüğü gibi henüz dava süreçleri tamamlanmadan Üçkuyular pazaryerinde inşaatı başlanan ve 72 kent suçundan bir diğeri olan İstinyePark AVM alanının bitişiğindedir. İzmir merkez ilçeler ve çevresinde henüz talep olmadan arz yarattığı düşünülen spekülatif kentsel rantın kent merkezinde kalan bütün askeri alanları olumsuz etkileme ve yabancılaştırma riski olduğu düşünülmektedir. Bu sebepten, tüm çeper kuşak alanlarının ve bu kapsamda detaylı incelenen askeri alanların korunması ve kamuya (yeniden) kazandırılmasına yönelik kapsamlı kentsel politikalar gerekmektedir.

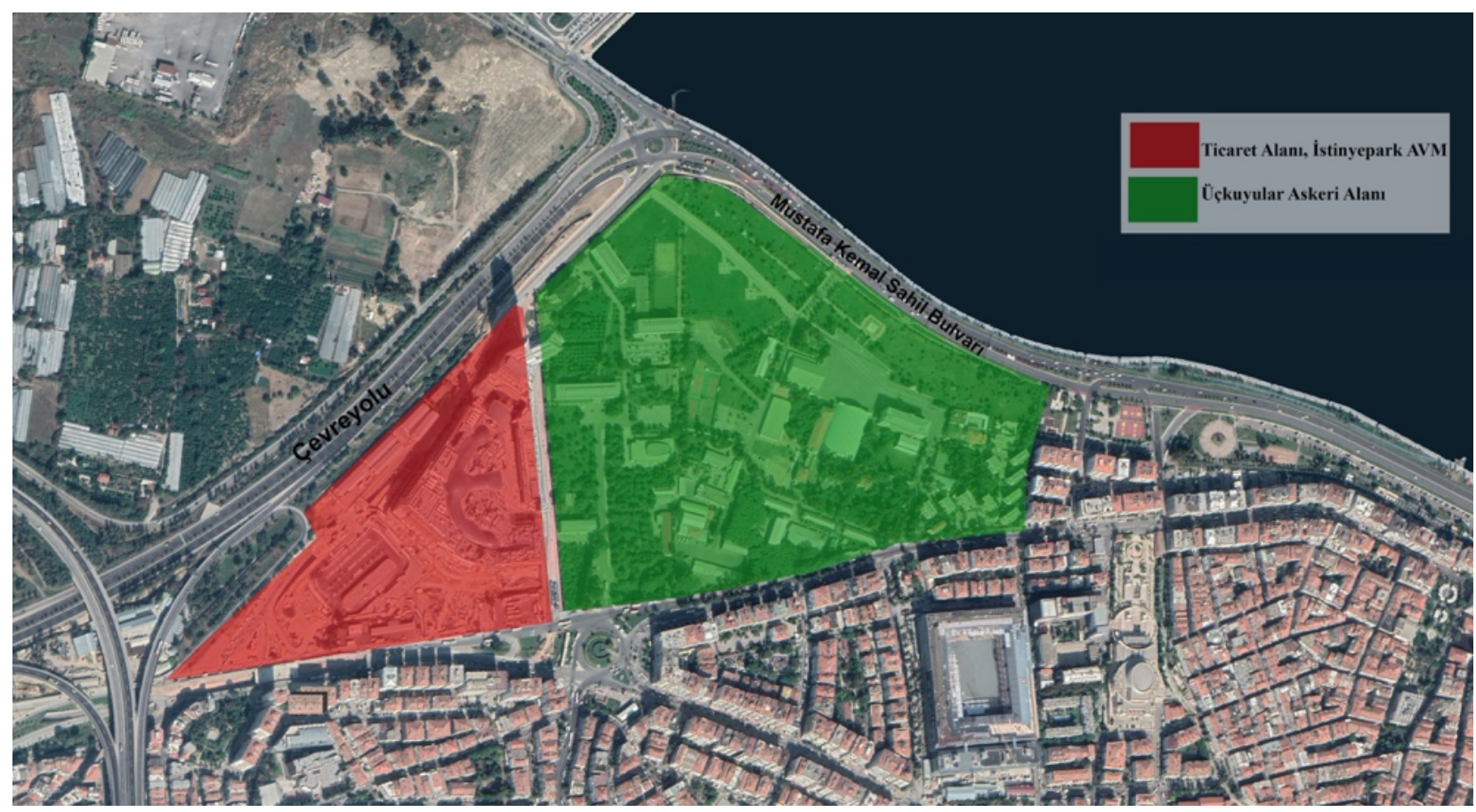

Şekil 2. İstinyepark AVM ve Üçkuyular Askeri Alanı, İzmir, 2019.

\section{Yöntem ve Bulgular}

Çalışmada, İzmir kent bütününde mevcut çeper kuşak alanları ve askeri alanlar Coğrafi Bilgi Sistemleri (CBS) teknikleri ile haritalandırılmış; bunun yanısıra, İzmir kenti için yine CBS haritalama ve konum tespit yöntemleri ile çeper kuşak planlaması ve yeşil kuşak önerisi yapılmıştır. Çeper kuşak planlaması yapılabilmesi için öncelikle şehirdeki mevcut çeper kuşak alanları tespit edilmelidir. Çeper kuşaklar, tarihi haritalar ve hava fotoğraflarının çakıştırılması ve/veya arazi kullanım bilgilerine ulaşılması yoluyla tespit edilebilirler. Çeper kuşak planlaması, planlama ve tasarım süreçlerinde kamu yararı ve kent ekolojisinin sürdürülebilirliği ve sermaye eliyle gerçekleştirilen yabancılaşma süreçlerinin engellenmesi için ciddi bir potansiyel taşımaktadır. Bu sebepten, çeper kuşak planlaması, yeşil altyapı stratejileri içerisinde önemli bir araç olabilir. Buna ek olarak çeper kuşaklar, kent merkezinde kalan açık ve yeşil alan kullanımlarıyla iklim değişikline uyum stratejileri içerisinde, kentlerin esnek uyum kapasitesinin (resilience) artırılması ve adaptasyonu (ör. afet toplanma alanları) ve kentsel ekolojik sürdürülebilirlik için anahtar unsurlardır.

İzmir'in çeper kuşak alanları liman ve liman arkası eski depo alanları, endüstri mirası yapıları ve mevcut endüstri alanları, askeri alanlar, mezarlıklar, bostanlar, Kordon, İnciraltı, Kültürpark vb. kent parkları ve rekreasyon alanları, stadyumlar, hipodrom, tren istasyonları, altyapı tesisleri, üniversite kampüsleri, OSB'ler, havaalanları, doğal yaşam parkı gibi kullanımları barındırmaktadır. Bu kullanımların bir kısmı 1923 Danger-Prost planında da görülebilmektedir (Karakaya, 2012). Açık yeşil alan kullanımlarına ve geniş parsellere sahip çeper kuşaklar sıklıkla ekolojik koridor özelliği gösterirler. Çeper kuşaklar, bütüncül ve sürekli bir yeşil kuşağın parçası olabilir ve/veya kamusal alan kullanımlarıyla yabancılaşmaya uğramadan çeper kuşak dönüşümü geçirebilirler. İzmir Büyükşehir Belediyesi tarafindan hazırlanan Yeşil Altyapı Stratejisi Raporunda (2017), çeper kuşak kullanımları içerisinde olan endüstri mirasları, kıyılar, ulaşım bağlantıları, yeşil alanlar, askeri alanlar, gecekondu alanları ve kentsel dönüşüm bölgeleri, 
İzmir yeşil kuşağı içerisine dahil edilebilecek alanlar olarak öne çıkmaktadır. Bu nedenle, çeper kuşak alanlarının tümünün yeşil altyap1 stratejisi içerisinde değerlendirilmesi önerilmektedir. Çeper kuşak planlaması, esnek uyum kapasitesini arttırıcı süreklilikte yeşil alanlar yaratılması, biyoçeşitliliğin ve ekolojik sürdürülebilirliğin arttırılması için bir potansiyeldir (Hazar \& Özkan, 2019).

Yapılan çalışma, İzmir'in merkez ilçelerindeki askeri alanları tespit etmekte ve Bornova Doğanlar Askeri alanında yaşanmış olan sürecin benzeri bir süreç yaşanmaması için, bu alanlarda kentsel ekoloji, kentsel süreklilik ve kamu yararı açılarından önemli olan çeper kuşak planlaması önermektedir. Bunu yaparken askeri alanların hem mekansal dağılımına hem de ilçe başına büyüklüklerine odaklanmaktadır. Çalışmada, askeri alanlar CBS araçları kullanılarak mekansallaştııılmış ve büyüklükleri oransal olarak değerlendirilmiştir. Bu alanların konumları hem mevcut kentsel doku hem de ekolojik koridorlar ile entegre bir yeşil alan sistemi planlaması açısından önemlidir. Büyüklükleri ise, halihazırda kişi başına düşen yeşil alan miktarı en az olan Karabağlar ve Gaziemir gibi ilçelere odaklanılması gerekliliğini öngörmektedir. İzmir'de mevcut yeşil alan ve askeri alanlarına dair sayısal veriler Tablo 1'de ve Şekil 3 'te gösterilmektedir.

Tablo 1. İzmir merkez ilçeler mevcut askeri alan ve yeşil alan büyüklükleri ( $\left.\mathrm{m}^{2}\right)$ (Şenol, 2019).

\begin{tabular}{|l|c|c|c|c|}
\hline İlçeler & Askeri Alan $\mathbf{( m}^{\mathbf{2}} \mathbf{~}$ & Yeşil Alan $\mathbf{( m}^{\mathbf{2}} \mathbf{~}$ & Nüfus (2019) & $\begin{array}{l}\text { Kişi Başına Düşen Yeşil Alan } \\
\mathbf{( m}^{\mathbf{2}} \mathbf{)}\end{array}$ \\
\hline Balçova & 2.090 .950 & 1.231 .803 & 79.681 & 15.45 \\
\hline Bayraklı & 1.342 .149 & 3.955 .144 & 312.264 & 12.66 \\
\hline Bornova & 7.825 .706 & 4.361 .520 & 450.992 & 5.67 \\
\hline Buca & 3.207 .495 & 2.770 .000 & 510.695 & 26.3 \\
\hline Çiğli & 11.564 .781 & 5.266 .281 & 200.211 & 5.29 \\
\hline Gaziemir & 13.220 .081 & 729.191 & 137.808 & 6.87 \\
\hline Güzelbahçe & - & 231.956 & 33.725 & 2.84 \\
\hline Karabağlar & 434.958 & 1.367 .737 & 480.925 & 4.77 \\
\hline Karşıyaka & - & 1.668 .528 & 349.290 & 6.72 \\
\hline Konak & 233.713 & 2.365 .039 & 351.572 & 10.06 \\
\hline Narlıdere & 26.279 .082 & 661.721 & 65.737 & \\
\hline
\end{tabular}

Tablo 1'de görüldüğü üzere, Narlıdere, Gaziemir ve Balçova ilçeleri yeşil alan miktarı az ilçeler olup; buna kıyasla oldukça yüksek askeri alan büyüklüğüne sahiptir. Askeri alanların kent merkezi dışına taşınması ardından (askeri alan barındırmayan Güzelbahçe ve Karşıyaka ilçeleri hariç) ilçelerin tümünde, askeri alanlar aracıllğıyla yeşil donatı miktarının arttırılması ve açık kamusal alan tasarımı yapılması için kentsel dokunun ve ekolojik koridorların detaylı analizi yapılmalıdır. 


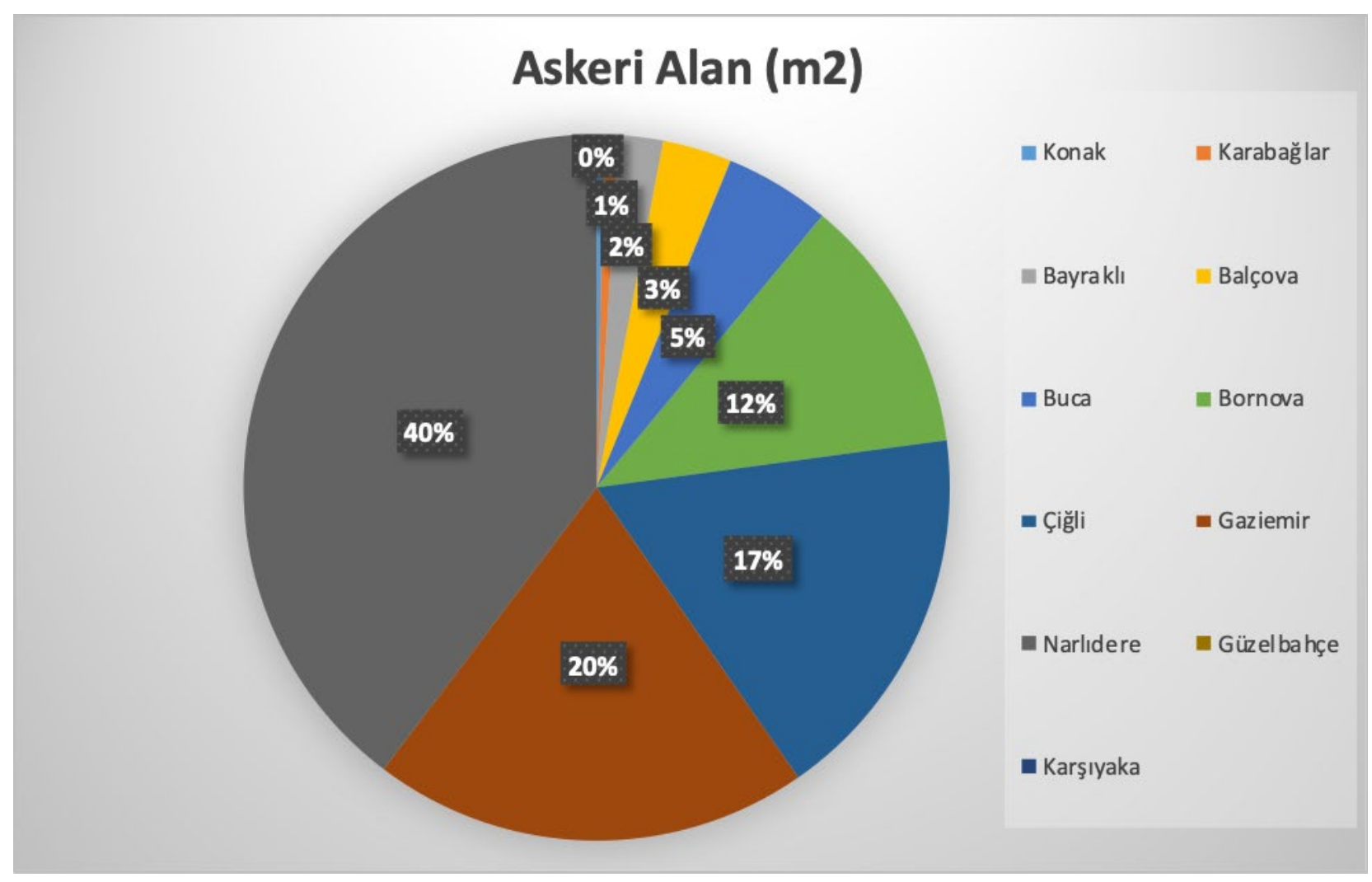

Şekil 3. İzmir merkez ilçeler askeri alan oranları (\%).

Şekil 3'te görüldüğü üzere, İzmir'deki en büyük askeri alan miktarına (m2) sahip ilçeler sırasıyla Narlıdere, Gaziemir, Çiğli, Bornova ve Buca'dır. Şekil 4'te İzmir'deki askeri alanların ilçelerdeki dağılımı mekansallaştırılmıştır. 


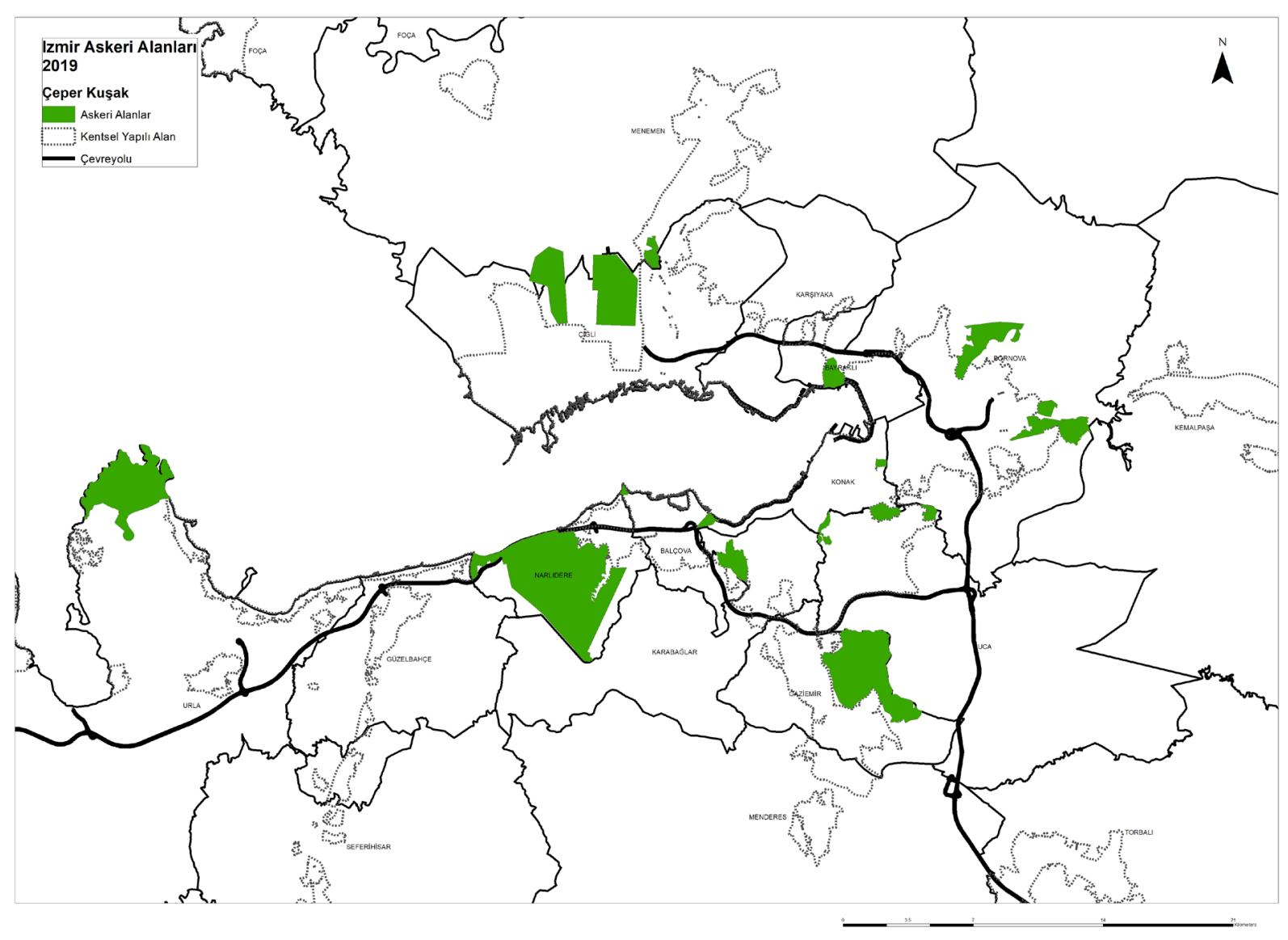

Şekil 4. İzmir askeri alanları, 2019.

Çalışmada, İzmir çeper kuşak alanları ve askeri alanlarının, Yeşil Altyapı Stratejisi Raporunda (2017) ekolojik koridor olarak işaretlenmiş olan nehir yataklarıyla ilişkisi gösterilerek, entegre bir yeşil kuşak hattı önerilmiş̧ir (Şekil 5-6). Şekil 5'te mekânsallaştırılan İzmir çeper kuşak alanları ve Şekil 6'da iç, orta ve dış çeperdeki konumlarına göre ayrılan askeri alanlar, bütüncül bir çeper kuşak planlaması ve tasarımı dahilinde, yeşil altyapı stratejileriyle entegre ve kent ekolojisi ve kamu yararı çerçevesinde değerlendirilmelidir. 


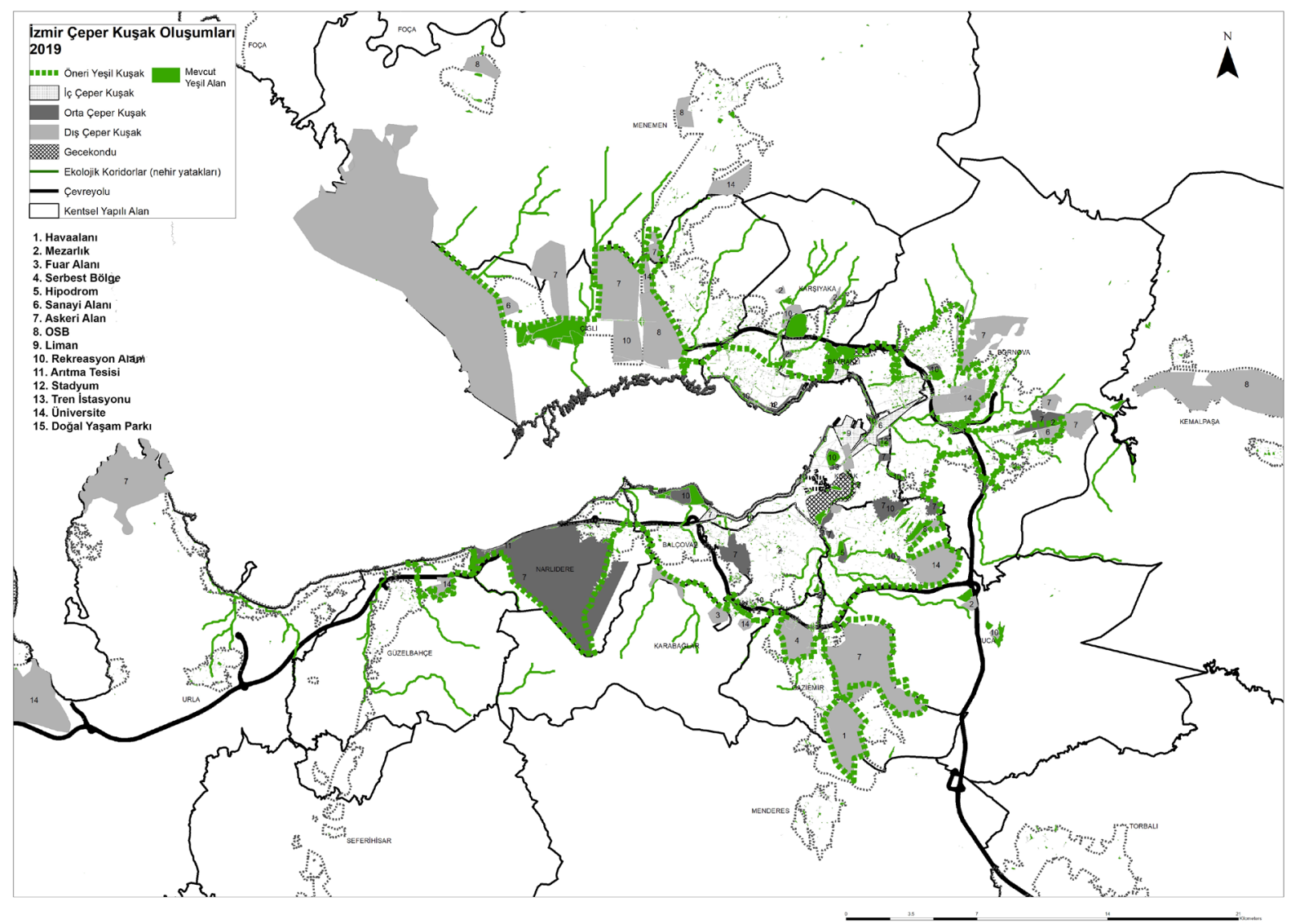

Şekil 5. İzmir çeper kuşak alanları ve öneri yeşil kuşak hattı (Hazar \& Özkan, 2019). 


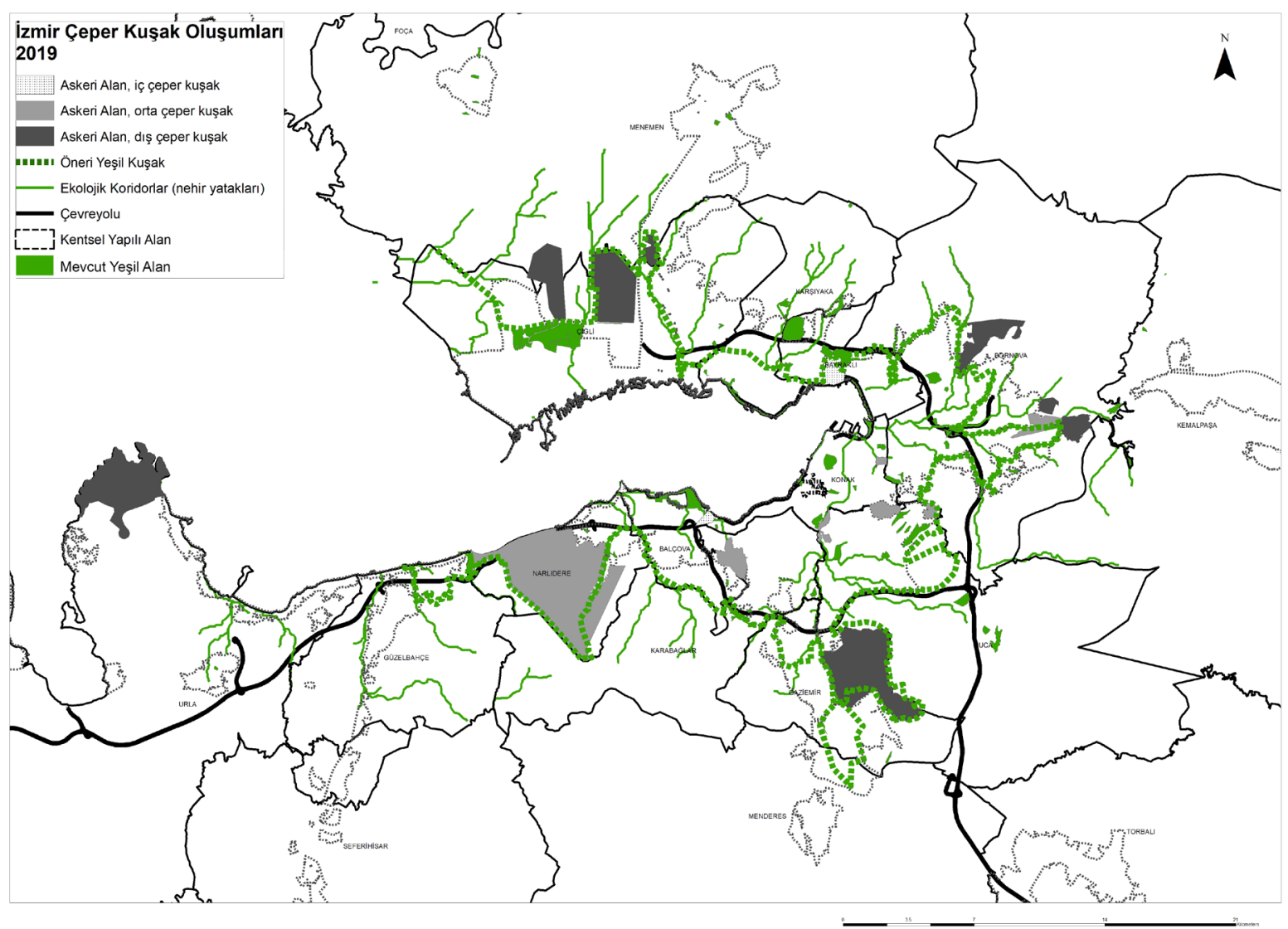

Şekil 6. İzmir askeri alanları, çeper kuşak oluşumları ve öneri yeşil kuşak hattı.

\section{SONUÇ:}

Çeper kuşak alanları, ülkemiz kent morfolojisi çalışmaları içerisinde yeni bir kavram olmakla beraber, son on yılda tezler, bildiriler, projeler ve makaleler aracılı̆̆ıyla sıklıkla araştırılmaya başlanmıştır. Kent içi yeşil alan tasarımı ve çeper kuşaklar arasındaki ilişkiye önceden yapılan çalışmalarda da dikkat çekilmesine rağmer(Ducom, 2003; Kukina, 2006), çeper kuşakların bütüncül yeşil kuşak politikaları ve yeşil altyapı stratejileri içerisinde ele alınması gerekliliğine dair daha çok araştırmaya ihtiyaç vardır.

Çeper kuşak haritalamasında Coğrafi Bilgi Sistemleri $\quad$ (CBS), Uzaktan Algılama vb . araçların kullanılmasının yaygınlaştırılması verilerin güvenilirliği için önerilmektedir . Daha kapsamlı analizler için, parsel bazlı dönüşüm süreçleri incelenmeli ve çeper kuşak planlaması kapsamında koruma planları ve kentsel tasarım projeleri yapılmalıdır Çeper kuşakların korunması, kamu yararı, kentsel kolektif belleğinin sürekliliği , kentsel kalite ve kentsel ekolojik sürdürülebilirlik açılarından önemlidir Bu bağlamda, yeşil kuşaklarla entegre bir çeper kuşak planlaması, İzmir için sürdürülebilir bir kentsel gelişim stratejisi yaratabilir.

Kent içinde kalan çeper kuşakların önemli bir bölümünü oluşturan askeri alanlar, geniş parselleri, açık ve yeşil alan kullanımları ve kamu mülkiyetinde olmaları sebebiyle gelecekte kent parkı ve kamusal alan olarak yeniden tasarlanabilme potansiyeli taşımaktadır. Özellikle iç ve orta çeper kuşak alanı olarak nitelendirebileceğimiz, kentsel yapılı alan içinde ve çevresinde kalan ve mevcut nehir yatakları ile buluşan askeri alanların (Şekil 6), halihazırda yeşil alan eksikliğini ve olası kentsel 1sı adası etkilerini ortadan kaldırma potansiyeli bulunmaktadır. Buna ek olarak, yoğun yeşil alan miktarına sahip askeri alanlar içerisindeki kapalı alan kullanımlarının dönüşümü de (askeri lojmanlar, sosyal tesisler vb.) kentsel bölgenin ihtiyaçları göz önüne alınarak ve kamusal kullanım öncelenerek yeni kullanımlara dönüştürülebilir (belediye lojmanı, sosyal tesis, kültür merkezi, kütüphane, kafeterya vb.). Ancak askeri alanlar 
üzerindeki dönüşüm, özelleştirme ve yabancılaşma baskıları kontrol edilmediği ve engellenmediği sürece, kentlerin ekolojik sürdürülebilirliği, kentsel kalite ve kent belleğinin risk altında olacağı gerçeği unutulmamalıdır.

\section{KAYNAKÇA:}

\section{Kitaplar:}

Barke, M. (2019). Fringe Belts. In JWR Whitehand and the Historico-geographical Approach to Urban Morphology (pp. 47-66). Springer, Cham.

Barke, M. (1990). Morphogenesis, fringe belts and urban size: an exploratory essay, in Slater, T.R. (ed.) The built form of Western cities, Leicester University Press 279-97, Leicester.

Halbwachs, M. (1950). Kolektif Bellek, çev. Zuhal Karagöz (Pinhan Yayıncılık, 2018).

İzmir Büyükşehir Belediyesi (2017). İzmir Yeşil Altyapı Stratejisi Raporu, Mart 2017.

Rossi, A. (1982). Architettura della città. Cambridge, MA: MIT Press.

\section{Makaleler:}

Conzen, M. R. G. (1969) Alnwick, Northumber- land: a study in town-plan analysis, Institute of British Geographers Publication 27, 2nd edn (Institute of British Geographers, London).

Conzen, M.P. (2009). How cities internalize their former urban fringes: a cross-cultural comparison. Urban Morphology 13, 29-51.

Ducom, E. (2003). Fringe Belts and Planning: a French example, Urban Morphology 7, 103-4.

Gu, K. (2010). Exploring the fringe belt concept in Auckland: An urban morphological idea and planning practice, New Zealand Geographer 66, 44-60.

Hazar, D., \& Kubat, A. S. (2015). Fringe belts in the process of urban planning and design: Comparative analyses of Istanbul and Barcelona, ITU A|Z Journal of Faculty of Architecture Vol. 12 No.1, 53-65, İstanbul.

Kukina, I. (2006) Fringe Belts and the Planning of Russian Cities, Urban Morphology 10, 145-6.

Özkan, S. P., Hazar, D., Özyiğit, M., Çelik, A., \& Aktaş, A. (2019). Sermayenin Mekân Arayışları: 2016-2018 Yılları Arası İzmir İnşaat Sektörü Örneği, Ege Mimarlık Vol. 104, sf. 52-57.

Şenol, F. (2019). Evaluation of Existing Neighborhood Parks based on the "Need-Based Equity": Why and who do and do (can) not use neighborhood parks in Izmir?, TÜBİTAK Projesi, https://doi.org/215K239.

Ünlü, T. (2013). Thinking about urban fringe belts: a Mediterranean perspective, Urban Morphology 17(1), 5-20.

Ünlü, T., \& Baş, Y. (2016). Multi-nuclear growth patterns in a rapidly changing Turkish city: a fringe-belt perspective, Urban Morphology 20 (2), 107-21.

Ünlü, T., \& Baş, Y. (2019). The Urban Growth and Development Periods of Turkish Cities: A Fringe-Belt Perspective. In Urban and Regional Planning in Turkey (107-128). Springer, Cham.

Whitehand, J. W. (1967). Fringe belts: a neglected aspect of urban geography. Transactions of the Institute of British Geographers, 223-233.

Whitehand, J. W. R., \& Morton, N. J. (2003). Fringe belts and the recycling of urban land: an academic concept and planning practice, Environment and Planning B: Planning and Design 30, 819-39.

Whitehand, J. W. R., \& Morton, N.J. (2004). Urban morphology and planning: the case of fringe belts, Cities 21(4), $275-89$. 
Whitehand, J. W. R., \& Gu, K. (2017). Urban fringe belts: evidence from China. Environment and Planning B: Urban Analytics and City Science, 44(1), 80-99.

\section{Bildiriler:}

Hazar, D., \& Kubat A. S. (2016). The fringe belt development process of Istanbul, Urban morphology and the resilient city: Proceedings from ISUF, 423-436, Nanjing.

Hazar, D., \& Özkan, S. P. (2019). Urban Fringe Belt Planning and Design as a Green Infrastructure Strategy, IDES'19 Symposium: Sustainability, Innovation, Production,Bildiri Tam Metin Kitab1, sf. 102-109.

Karakaya, E. (2012). Reconstruction of Anatolia for the Construction of Nation-State: Roles Attained to Ankara and İzmir, 15th International Planning History Society (IPHS) Conference, Sao Paulo, Brezilya.

Kaya, A. Y. \& Akdemir, İ. O. (2019). Çeper Kuşakların Mekansal Büyüme Üzerindeki Etkisi, 2nd International Social Sciences \& Innovation Congress, Firat Üniversitesi, Elazığ.

Kubat, A. S. (2019). Exploring the Fringe-Belt Phenomenon in a Multi-Nuclear City: The Case of Istanbul. Iconarp International Journal of Architecture and Planning, 7, 95-134.

Kubat, A. S., \& Hazar, D. (2018). İstanbul'un Çeper Kuşak Gelişim Süreci, II. Kentsel Morfoloji Sempozyumu: "DeğişKent” Değişen Kent, Mekân ve Biçim Bildiriler Kitabı, İstanbul Teknik Üniversitesi, sf. 693-711.

\section{Tezler:}

Hazar, D. (2012). Kentsel Planlama ve Tasarım Süreçlerinde Kentsel Kuşak Alanları: İstanbul ve Barselona Kentleri Karşıllaştırmalı Değerlendirmesi, Yüksek Lisans Tezi, İstanbul Teknik Üniversitesi, İstanbul.

\section{Web siteleri:}

TMMOB İZMİR İKK (2018). Askeri Alanlar Ranta Açılmasın, Kent Parkı Yapılsın, Basın Açılaması, http://www.izmimod.org.tr/v2/haberler/1007-tmmob-izmir-ikk-askeri-alanlar-ranta-acilmasin-kent-parki-yapilsin, Erişim Tarihi: 30.01.2020.

TMMOB İZMIR İKK (2019). İzmir Kent Suçları Haritası, http://kentsuclari.org, Erişim tarihi: 31.01.2020.

Url-1: Askeri Alanların Şehir Dışına Taşınması Emirdir, http://www.yapi.com.tr/haberler/askeri-alanlarin-sehirdisina-tasinmasi-emirdir_152249.html, Erişim tarihi: 30.01.2020.

Url-2: Askeri kışlaların taşınması için 3 bakanlıktan oluşan komisyon kuruldu, https://www.cnnturk.com/turkiye/askeri-kislalarin-tasinmasi-icin-3-bakanliktan-olusan-komisyon-kuruldu, $\quad$ Erişim tarihi: 30.01.2020.

Url-3: Bornova Hacılarkırı'ndaki imar değişikliğine mahkeme engeli, https://www.birgun.net/haber/bornovahacilarkiri-ndaki-imar-degisikligine-mahkeme-engeli-282569, Erişim tarihi: 30.01.2020. 